\title{
"The Influence of Economic Growth, BI Rate, and Inflation and the Impact on Direct Foreign Investment in Indonesia in 2010-2017"9
}

\section{Dadang Saepuloh, Srie Nuning Mulatsih, and Sutarjo}

Universitas Islam Syekh-Yusuf

\section{Abstract}

Foreign direct investment (FDI) is a long-term investment for developing countries. FDI is very helpful for Indonesia in economic development. Increased foreign investment can directly improve the living standards of Indonesian people. Foreign investment can make a company capable of controlling international business operations and increase more profits. Whereas indirect foreign investment in the form of portfolio investment in the form of investments in financial assets such as stocks and bonds.Foreign Investment (PMA) during the study period has a minimum value of 7.13 and a maximum value of 9.44 . Then obtained the mean or average value of 8.4341 and obtained the standard deviation value of 74765 . Judging from the standard deviation that has the highest value is the $\mathrm{SBI}$, which is 1.05446 , this shows that $\mathrm{SBI}$ is more varied than other data. And the standard deviation that has the lowest value is GDP, which is 0.24816 , this shows that GDP is homogeneous compared to others. Based on the calculation $F$ Test is the Fcount value is 364,546 . While the Ftable value is 2.92. Means that the Fcount value is $364,546>$ Ftable 2,92. Then $\mathrm{HO}$ is rejected and $\mathrm{Ha}$ is accepted. Based on a significance value of 0,000 smaller than 0.05 . This shows that Gross Domestic Product, Blinterstrate, and Inflation have a significant effect on FDI simultaneously.

Keywords: Foreign direct investment, economic development,value

\section{Introduction}

Foreign investment flows to developing countries in Asia have increased rapidly since the 1990s. There was a crisis in mid-1997-1999 which led to the weakening of the Indonesian economy, which was seen from falling economic growth which also caused foreign investment to decline. The flow of foreign investment began to increase again after the crisis. However, the capital increase from foreign investment to Indonesia is 
Direct Investment) or foreign direct investment which aims to increase funding funds. FDI capital inflows are long-term and vulnerable to economic turmoil.

Foreign investment is divided into two, namely foreign direct investment and indirect foreign investment (portfolio). Foreign direct investment is considered more beneficial than indirect foreign investment because the effect is capital which can really be felt directly by the state. While foreign investment is not direct, it is fluctuating, making it vulnerable to economic turmoil.

FDI is a long-term investment for developing countries. FDI is very helpful for Indonesia in economic development. Increased foreign investment can directly improve the living standards of Indonesian people. Foreign investment can make a company capable of controlling international business operations and increase more profits. Whereas indirect foreign investment in the form of portfolio investment in the form of investments in financial assets such as stocks and bonds.

Mudrajad (2004) mentions that there are a number of factors that greatly influence whether or not the climate of investment in a country is good. These factors are not only related to inefficient government bureaucracy, inadequate infrastructure, policy instability, corruption, still low access to financing, labor regulations, which are considered restrictive, poor tax regulation, unstable inflation and foreign exchange rates, limited educated workforce and others. But also influenced by economic stability, which is reflected in the stable exchange rate of a country's currency, relatively stable inflation, interest rates and economic growth of a country are also one of the factors that are highly regarded by foreign investors and domestic investors.

A good rate of economic growth will affect investor interest in investing in Indonesia. Good economic growth is marked by an increase in the economy of a country. The number used to estimate changes in a country's output is its monetary value (money) which is reflected in the value of GDP (Gross Domestic Product). To measure economic growth, GDP is used based on constant prices. Changes in GDP values indicate changes in the quantity.

Changes in interest rates can affect the desire of investors to invest because in general changes in $\mathrm{Bl}$ interest rates can affect the size of deposit rates and credit interest rates in the community. When interest rates increase, investor interest in investing in Indonesia decreases. This happens because if the interest rate rises, the cost for the construction and operation of a company also requires more funds. Conversely, if the interest rate decreases, it will encourage the interest of investors to invest in Indonesia.

Inflation occurs if there is a general increase in prices of goods and continues. A high level of inflation can lead to a decrease in company profits because the prices 
of goods and services are less competitive. In a state of high inflation, real money values drop dramatically, people tend not to have cash. So as to encourage people to conduct transactions in the form of barter which is usually followed by a decrease in the production of goods, so as to hamper new investment.

Based on data from previous studies that are inconsistent, the authors are motivated to conduct research to re-analyze the influence of several macroeconomic factors on foreign direct investment in Indonesia. This study raises three independent variables, namely economic growth, $\mathrm{Bl}$ interest rates, and inflation, and one dependent variable, namely direct foreign investment. Based on the above background, the author is interested in conducting a study entitled "Analysis of Economic Growth, BI Interest Rates, and Inflation and the Impact on Foreign Direct Investment (FDI) in Indonesia in 20102017".

\subsection{Problem formulation}

Based on the background and identification of the problem mentioned above, then the problem in this research is formulated as follows:

1. What is the impact of Economic Growth on Foreign Direct Investment (FDI) in Indonesia?

2. What is the impact of $\mathrm{BI}$ interest rates on foreign direct investment (FDI) in Indonesia?

3. What is the impact of Inflation on Foreign Direct Investment (FDI) in Indonesia?

4. What is the impact of Economic Growth, BI Interest Rates and Inflation on Foreign Direct Investment (FDI) in Indonesia?

\section{Literature Review}

In this study the dependent variable is Foreign Direct Investment or often referred to as Foreign Investment (PMA). Independent variables are Economic Growth, BI Interest Rates, and Inflation. Here are the operational definitions per variable:

\subsection{Direct foreign investment}

Kumar and Pradhan (2002) also say that "Foreign Direct Investment is the most important source of external resource flows to developing countries after the 1990s and has 
become a significant capital formation for these countries. FDI will contribute to more than proportional economic growth for the host country. Furthermore, FDI is usually accompanied by the transfer of production methods and managerial abilities from developed countries to developing countries.

S Sassen-Koob (1984). "Foreign direct investment is used as an indicator for internationalization whose focus is on export manufacturing investment"

\subsection{Economic growth}

Economic growth is the economic condition of a country where it experiences an increase towards a better sustainable or sustainable within a certain period of time. An economy is said to experience economic growth if the amount of production of goods and services increases. The figure used to measure economic growth in estimating changes in output is its monetary value (money) which is reflected in Gross Domestic Product (GDP). GDP value used is GDP based on constant prices. Because by using constant prices, the effect of price changes has been eliminated, so that even if the number that appears is the money value of the total output of goods and services, changes in GDP value while showing changes in the quantity of goods and services produced during the observation period (Rahardja and Manurung, 2016: 141).

Economic growth is an increase in the production of goods and services in an economy which is shown in quantitative changes (Nanga, 2005: 273). Increased economic growth will affect the increase in welfare, employment opportunities, as well as productivity and income distribution. If production of goods and services increases, the economy of a country can be said to increase as well (Rahardja and Manurung 2008: 129).

Prof. Moslow in Robert M. Solow (2016) states that "The future and future will be constrained if the natural resource base narrows over time in terms of variants of the eponymous growth model to analyze the relationship between resource input ratios and GNP in the United States during mid-season two seconds and twenty".

"Outward FDI is positively related to growth. This finding is strong for several model specifications, potential outliers, and different estimation techniques. In addition, the Granger causality test for the US shows that causality is two-way, indicating that increasing FDI out is the cause and consequence of increasing domestic output " (Dierk Herzer: 2009). 


\subsection{BI rate}

Interest rate is the price that must be paid for the use of money for a certain period of time, which is usually expressed in percent (\%) (Boediono, 2008: 2). The interest rate is determined by the demand and supply of money and is determined in the money market. Changes in interest rates will affect the desire to invest. These interest rates can be divided into two, namely nominal interest rates and real interest rates.

\subsection{Inflation}

Inflation is a tendency to increase price levels continuously, affecting individuals, businesses, and government (Latumaerisa, 2012: 22). Inflation occurs when the increase extends to most goods and services in the economy and continues continuously (because if the price increase is only temporary, it cannot be said to be inflation).

"Tests conducted on granger causality provide support for the Friedman-Ball hypothesis that an increase in inflation causes an increase in inflation uncertainty in each country" (James E. Payne: 2007)

J. Evert (1984) states that "for projects that are fully funded by loans, the benefits of additional taxes on interest costs exceed the additional tax costs on depreciation allowances" J.E. Everett

\section{Methodology}

\subsection{Research methods}

This research is a type of descriptive research. The approach used in this study is a quantitative approach.

The population of this study is Economic Growth, BI Interest Rates, and Inflation in Indonesia. The sample used in this study were 32 samples obtained from Economic Growth, BI Interest Rates, and Inflation in Indonesia in 2010 - 2017 (8 years x 4 quarters $=32$ ). In this study the independent variables are Economic Growth (X1), BI Interest Rate (X2) and Inflation (X3) in Indonesia. The dependent variable is Direct Foreign Investment (Y1). 


\subsection{Method of collecting data}

The data used in this study is secondary data in the form of time series or periodic. Documentation techniques are based on several sources including the Indonesian economic report from various editions published by the Central Bureau of Statistics, Bank Indonesia, and the Coordinating and Investment Board. Data for all variables that will be studied begin from 2010 to 2017.3.4. Operational definitionResearch variables are attributes or properties or values of people, objects or activities that have certain variations set by researchers to be studied and then drawn conclusions (Sugiyono, 2013: 3). In this study the dependent variable is Foreign Direct Investment or often referred to as Foreign Investment (PMA). Independent variables are Economic Growth, BI Interest Rates, and Inflation. Following are the operational definitions per variable.

\section{Result}

4.1.

Global economic development is driving positive growth in direct investment in the world. A company from one country invests in the long run. In Indonesia the value of realization of foreign direct investment each year tends to increase. The main countries as the countries that invest their capital in Indonesia are developed countries where they can see the opportunities available to invest heavily in the long term.

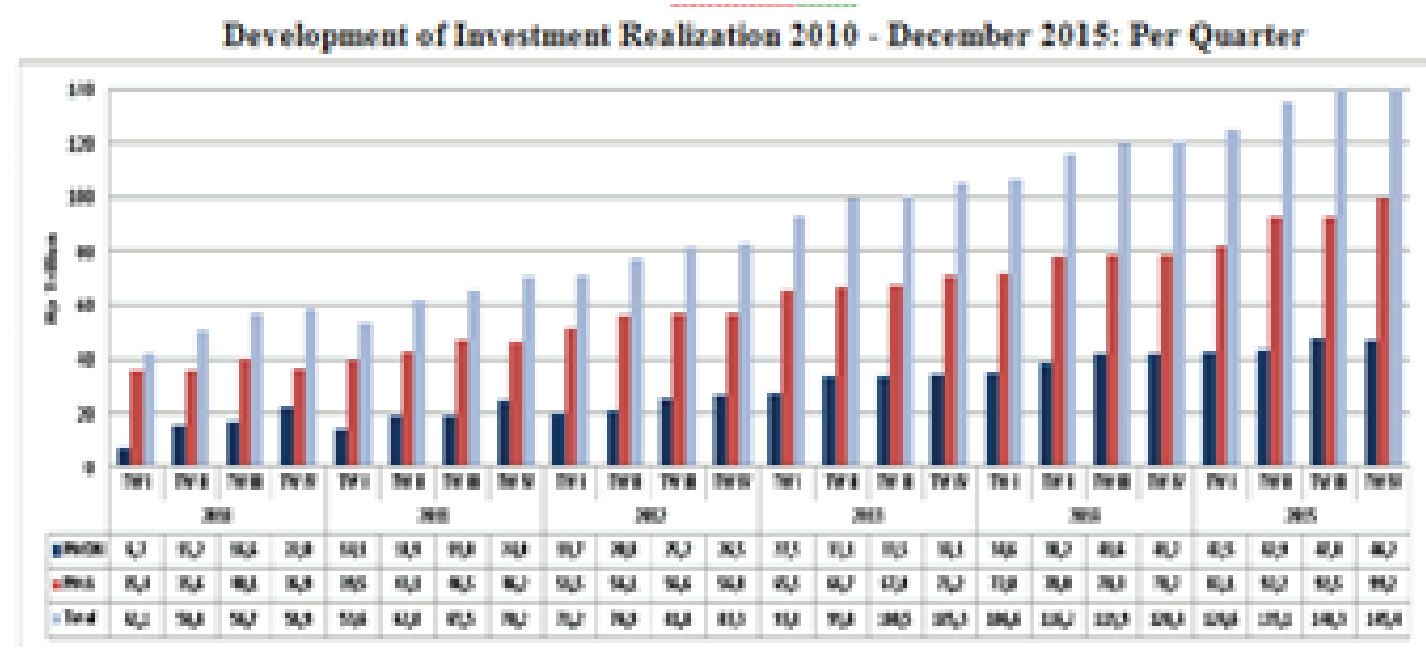

Soures : bkpm (2015)

The development of foreign investment realization in Indonesia in 2010 to 2015 has always increased every year. The results of investment realization in 2015 amounted to Rp. 545.4 trillion, an increase of $17.8 \%$ compared to the same period in the previous 
year. This achievement exceeded the limit in 2015. Foreign direct investment (FDI) also increased by $19.2 \%$ to Rp 365.9 trillion. The positive achievement of the JanuaryDecember 2015 investment realization gave optimism that the prospects for Indonesia's investment in the future were still quite good. In addition, the government has issued various policy packages with various investment incentive options, simplification of licensing and various facilities for investors, including facilitation of problems faced by investors.

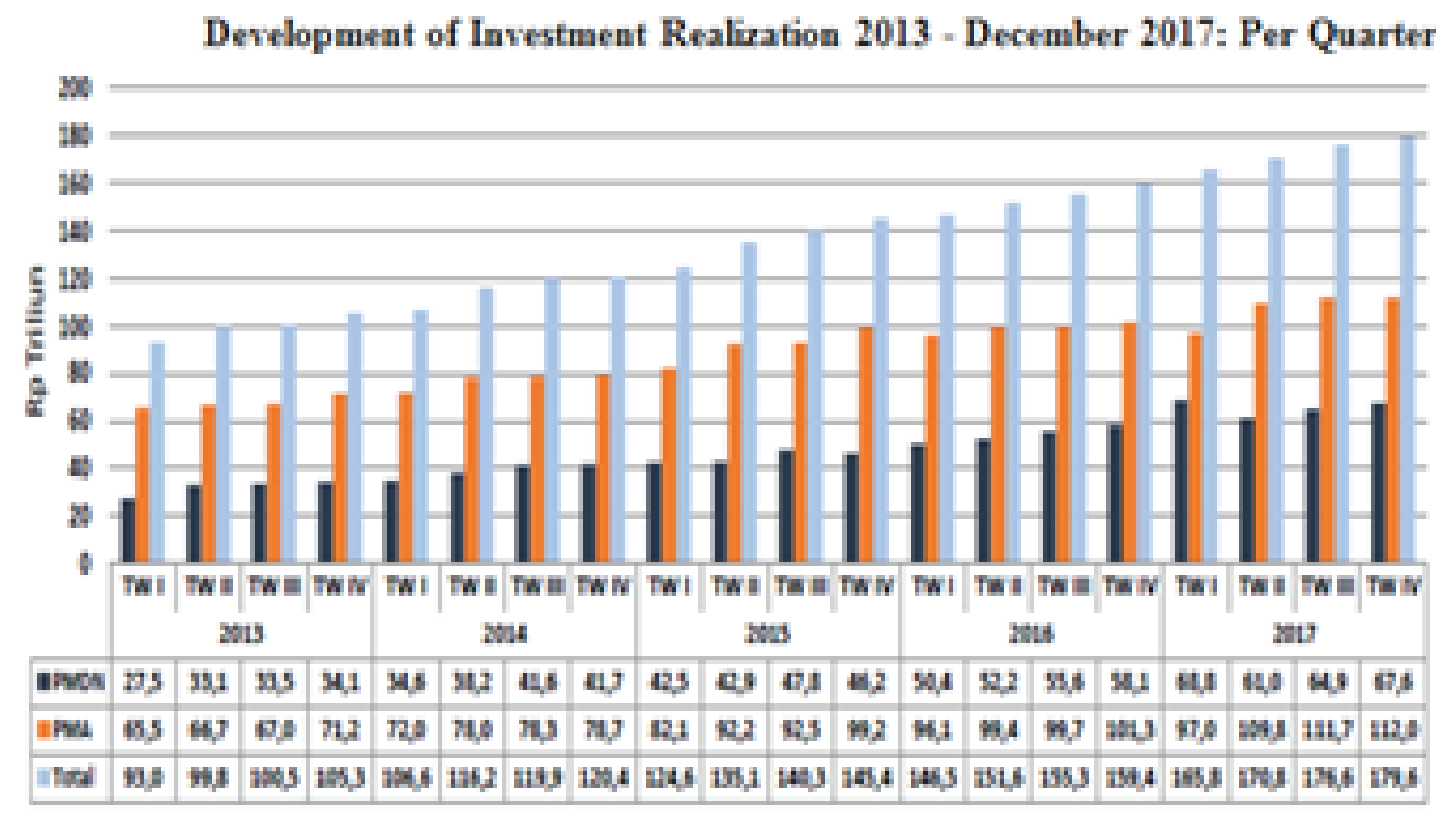

Source blum (2018)

The realization of foreign investment in Indonesia in 2013-2017 has increased every year. Realization of FDI investments based on country origin (top 5) are Singapore (US \$ 8.4 billion, 26.2\%); Japan (US \$ 5.0 billion, 15.5\%); R. R. China (US \$ 3.4 billion, 10.4\%); Hong Kong, China (US \$ 2.1 billion, 6.6\%); and South Korea (US \$ 2.0 billion, 6.3\%). Realization of FDI investments based on business sectors (top 5) are: Electricity, Gas and Water (US \$ 1.6 billion); Mining (US \$ 1.2 billion); Transportation, Warehouse and Telecommunications (US \$ 1.0 billion); Housing, Industrial Estate and Offices (US \$ 0.8 billion); and Basic Metal, Metal, Machinery and Electronic Industries (US \$ 0.6 billion). If all industrial sectors are combined, the industry can contribute US \$ 2.7 billion or 31.9\% of total FDI. Realization of FDI investments based on project location (top 5) are: West Java (US \$ 5.1 billion); DKI Jakarta (US \$ 4.6 billion); Banten (US \$ 3.0 billion); Central Java (US \$ 2.4 billion); and Papua (US \$ 1.9 billion). 


\section{2.}

Based on the results of the study showed that in this study the number of observations was 32. GDP during the study period had a minimum value of 14.81 and a maximum value of 15.69. Then the mean or average value obtained is equal to 15.2769 and the standard deviation value is 0.24816 . SBI during the study period has a minimum value of 4.25 and a maximum value of 7.75. Then obtained the mean or average value of 6.3438 and obtained the standard deviation value of 1.05446. INF during the study period has a minimum value of -, 35 and a maximum value of 2.46 . Then the mean or average value obtained is equal to, 4444 and obtained the standard deviation value of, 51751. PMA during the study period has a minimum value of 7.13 and a maximum value of 9.44. Then obtained the mean or average value of 8.4341 and obtained the standard deviation value of 74765 . Judging from the standard deviation that has the highest value is the SBI, which is 1.05446 , this shows that $\mathrm{SBI}$ is more varied than other data. And the standard deviation that has the lowest value is GDP, which is 0.24816 , this shows that GDP is homogeneous compared to others.

\subsection{Normality}

\begin{tabular}{|c|c|c|}
\hline \multicolumn{3}{|c|}{ One-Sample Kolmogorov-Smirnov Test } \\
\hline & & $\begin{array}{c}\text { Unstandardized } \\
\text { Residual }\end{array}$ \\
\hline \multicolumn{2}{|l|}{$\mathbf{N}$} & 32 \\
\hline \multirow[t]{2}{*}{$\begin{array}{l}\text { Normal } \\
\text { Parameters.. }\end{array}$} & Mean & .0000000 \\
\hline & $\begin{array}{l}\text { Std. } \\
\text { Deviation }\end{array}$ & .11812815 \\
\hline \multirow{3}{*}{$\begin{array}{l}\text { Most } \\
\text { Extreme } \\
\text { Differences }\end{array}$} & Absolute & .119 \\
\hline & Positive & .113 \\
\hline & Negative & -.119 \\
\hline \multicolumn{2}{|l|}{ Test Statistic } & 119 \\
\hline \multicolumn{2}{|c|}{ Asymp. Sig- (2-tailed) } & $200^{\circ}$ \\
\hline
\end{tabular}

Based on the results of the data in the calculation shows that the data is normally distributed. This is indicated by a significance value of 0.200 which is greater than the value of 0.05 . 


\subsection{Multicollenerity}

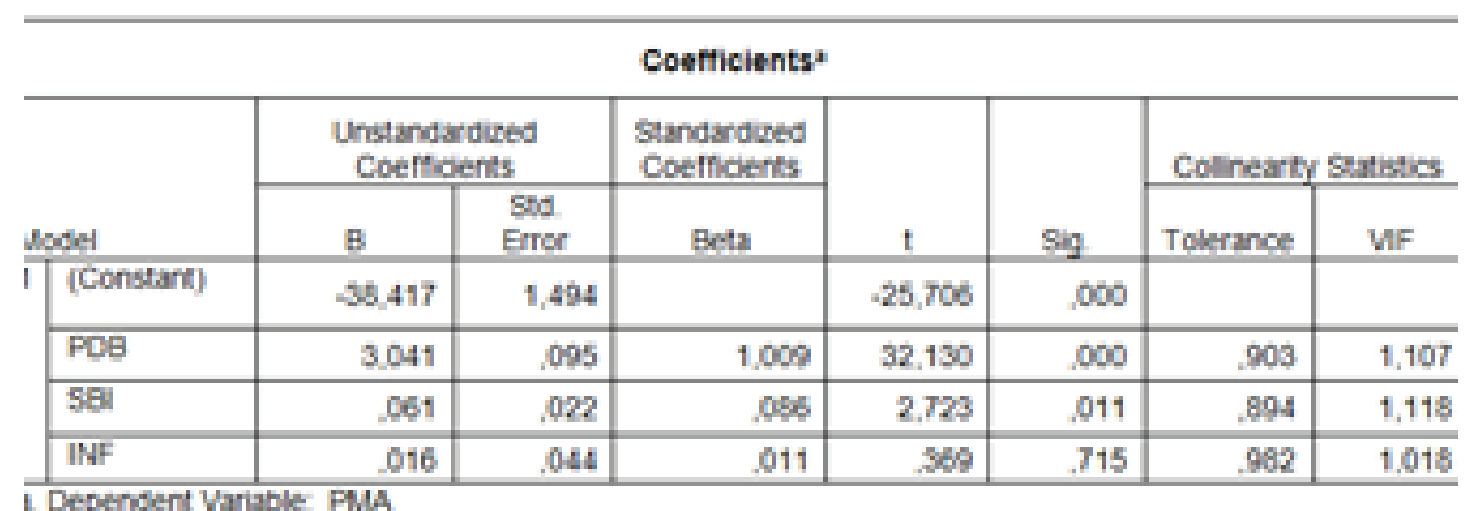

Lependent thinble FWL

ource Ompa SPSS Fonion 24

From the test results indicate that there is no multicolinearity between the independent variables in the study because the VIF value is less than 10 and the tolerance value is greater than 0.10 .

\subsection{Heterocedacity}

\section{Cotficienty}

\begin{tabular}{|c|c|c|c|c|c|c|c|c|}
\hline \multirow{2}{*}{\multicolumn{2}{|c|}{ Moded }} & \multicolumn{2}{|c|}{$\begin{array}{l}\text { Unsundarded } \\
\text { Coeffiderts }\end{array}$} & \multirow{2}{*}{$\begin{array}{c}\text { Sundurdat } \\
\text { Coetfoerts } \\
\text { Bela }\end{array}$} & \multirow[b]{2}{*}{1} & \multirow[b]{2}{*}{$\mathrm{Sg}$} & \multicolumn{2}{|c|}{ Colneary Statsts } \\
\hline & & B & $\begin{array}{l}\text { Sid } \\
\text { Enar }\end{array}$ & & & & Tolerance & VF \\
\hline \multirow[t]{4}{*}{1} & (Consunt] & 3547 & 1,54 & & $-66,706$ & 000 & & \\
\hline & POB & 3041 & 005 & 1,000 & 3,130 & $\infty 00$ & , & 1,107 \\
\hline & sti & 061 & $0 \alpha$ & 606 & $2 \pi$ & 011 & 804 & 1,118 \\
\hline & INF & 016 & (1044 & 011 & 30 & 715 & 96 & 1,016 \\
\hline
\end{tabular}

a Detenderl Vrible PMA

\section{Sumce: Oupu SPS Voino 2}

Park Test Results obtained the significance value of all independent variables greater than 0.05 . Having a GDP value of $0.121 \mathrm{SBI}$ of 0.233 and INF of 0.781 . With a significance value of 0.05 or not significant to the dependent variable Logarithm Natural Residual squared, it can be assumed that the regression model in this study does not occurheteroscedasticity. 


\subsection{Autocorrelation test}

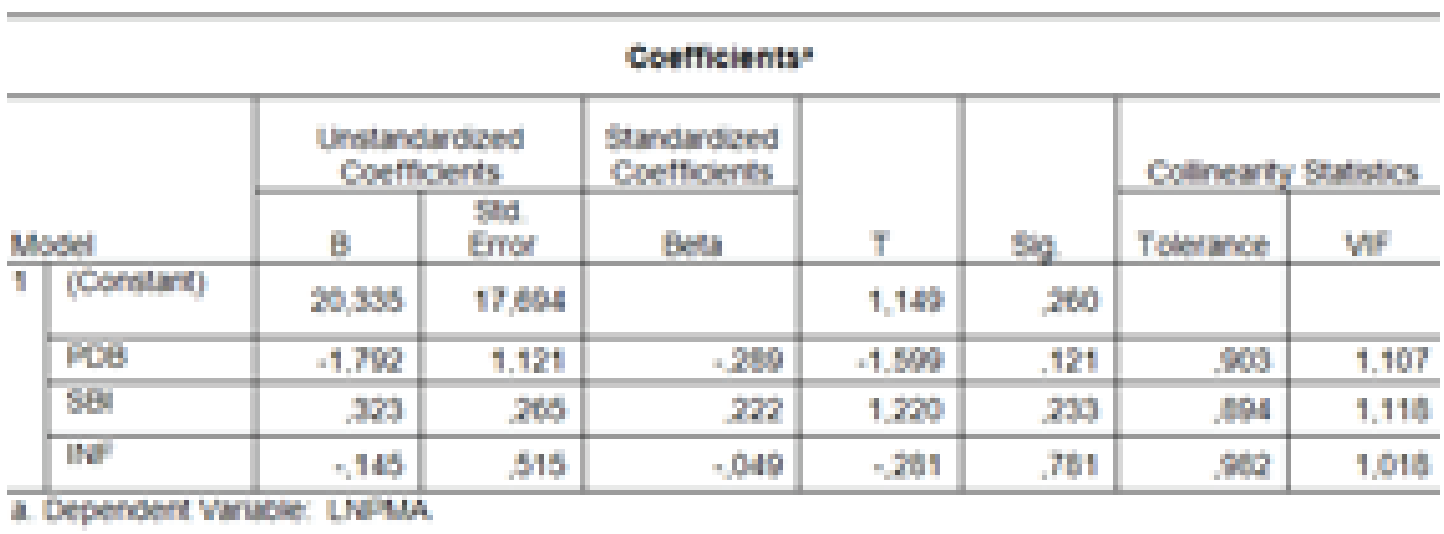

\section{Sourct: Output spss Vard24}

Based on the calculation of the probability value 0.369 is not significant at 0.05 , which means that the null hypothesis is accepted so that the residual does not occurautocolerasi.

\subsection{Multiple regression analysis}

\begin{tabular}{|c|c|c|c|c|c|}
\hline \multicolumn{6}{|c|}{ Model Summary } \\
\hline Model & $\mathrm{R}$ & $\begin{array}{c}\mathrm{R} \\
\text { Square } \\
\end{array}$ & $\begin{array}{l}\text { Adjusted R } \\
\text { Square }\end{array}$ & $\begin{array}{l}\text { Std Error of } \\
\text { the Estimate }\end{array}$ & Durbin-Watson \\
\hline 1 & $987 \circ$ & 975 & 972 &, 12430 & 1,558 \\
\hline \multicolumn{6}{|c|}{ a. Predictors: (Constant), INF, PDB, SBI } \\
\hline b. Depe & Variab & PMA & & & \\
\hline
\end{tabular}

Multiple regression analysis can be seen from table 4.13 with the regression equation as follows:PMA $=-38,417+3,041 \mathrm{PDB}+0,061 \mathrm{SBI}+0,016 \mathrm{INF}+$ eBased on the results of the regression equation above it can be explained as follows:a. A constant coefficient of -38.417 means that FDI will decrease by 38.417 if GDP, SBI, INF are respectively 0.b. GDP value has a regression coefficient value of 3.041. This means that if there is an increase in GDP value of 1, assuming other variables are constant, there will be an increase in FDI of 304.1\%.c. The SBI value has a regression coefficient of 0.061 . This means that if there is an increase in the SBI value of 1 , assuming other variables are constant, there will be an increase in FDI of 6.1\%.d. The INF value has a regression coefficient of 0.016 . 
This means that if there is an increase in the INF value of 1, assuming another variable is constant, there will be an increase in FDI of $1.6 \%$.

Based on the calculation can be seen the value of Adjusted R-square is equal to 0.972. This means that $97.2 \%$ of the dependent variable (PMA) can be explained significantly by the variation of independent variables (independent). While the remaining $2.8 \%$ is explained by other variables not included in the regression model in this study. 


\subsection{T test}

\begin{tabular}{|c|c|}
\hline \multicolumn{2}{|c|}{ Runs Tast } \\
\hline & 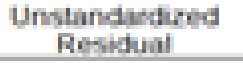 \\
\hline Terst Walue & -01577 \\
\hline Caven - Tas Valu & 16 \\
\hline $\begin{array}{l}\text { Cusers in Tosl } \\
\text { Vhue }\end{array}$ & 16 \\
\hline Toth Cases: & 32 \\
\hline Humber of Runs & 14 \\
\hline 2 & - \\
\hline $\begin{array}{l}\text { Asymp sia l2 } \\
\text { sulod }\end{array}$ & 30 \\
\hline 1. Maktion & \\
\hline
\end{tabular}

\begin{tabular}{|c|c|c|c|c|c|c|c|c|}
\hline \multicolumn{9}{|c|}{ Coefficientsa } \\
\hline & & \multicolumn{2}{|c|}{$\begin{array}{l}\text { Unstandardized } \\
\text { Coefficients }\end{array}$} & \multirow{2}{*}{$\begin{array}{c}\text { Standardized } \\
\text { Coefficients } \\
\text { Beta }\end{array}$} & \multirow[b]{2}{*}{$\mathrm{t}$} & \multirow[b]{2}{*}{ Sig. } & \multicolumn{2}{|c|}{ Collinearity Statistics } \\
\hline \multicolumn{2}{|c|}{ Model } & B & $\begin{array}{l}\text { Std. } \\
\text { Error }\end{array}$ & & & & Tolerance & VIF \\
\hline \multirow[t]{4}{*}{1} & (Constant) & $-38,417$ & 1,494 & & $-25,706$ &, 000 & & \\
\hline & PDB & 3,041 & 095 & 1,009 & 32,130 & 000 & ,903 & 1,107 \\
\hline & SBI & 061 & 022 & 086 & 2,723 & 011 & 894 & 1,118 \\
\hline & INF & 016 & 044 & 011 & 369 & ,715 & ,982 & 1,018 \\
\hline
\end{tabular}

\section{Source: Output SPSS Vertion 24}

\begin{tabular}{|c|c|c|c|c|c|c|c|c|}
\hline \multicolumn{9}{|c|}{ Coefficients ${ }^{a}$} \\
\hline \multirow{2}{*}{\multicolumn{2}{|c|}{ Model }} & \multicolumn{2}{|c|}{$\begin{array}{l}\text { Unstandardized } \\
\text { Coefficients }\end{array}$} & \multirow{2}{*}{$\begin{array}{c}\text { Standardized } \\
\text { Coefficients } \\
\text { Beta }\end{array}$} & \multirow[b]{2}{*}{$\mathrm{T}$} & \multirow[b]{2}{*}{ Sig. } & \multicolumn{2}{|c|}{ Collinearity Statistics } \\
\hline & & $\mathrm{B}$ & $\begin{array}{l}\text { Std. } \\
\text { Error }\end{array}$ & & & & Tolerance & VIF \\
\hline$\overline{1}$ & (Constant) & $-38,417$ & 1,494 & & $-25,706$ &, 000 & & \\
\hline & PDB & 3,041 &, 095 & 1,009 & 32,130 &, 000 &, 903 & 1,107 \\
\hline & SBI & 061 & 022 & 086 & 2,723 & 011 & 894 & 1,118 \\
\hline & INF & 016 &, 044 & 011 & 369 & ,715 & ,982 & 1,018 \\
\hline
\end{tabular}

a. Dependent Variable: PMA

\section{urce: Output SPSS Vertion 24}

\subsubsection{Effect of gross domestic product on foreign investment}

The first hypothesis in this study is the influence of GDP on foreign investment. From the results of the calculation of the significance test partially obtained the GDP tcount of 32.130 and with a significance value of 0.000 less than 0.05 and the value of ttable 
$2.042<$ tcount 32.130. Then $\mathrm{Ha}$ is accepted and $\mathrm{Ho}$ is rejected which means that it has an effect and is significant between GDP and PMA. Thus $\mathrm{H} 1$ which states that Gross Domestic Product has an effect on Foreign Investment is accepted.

\subsubsection{Effect of $B I$ interest rates on foreign investment}

The second hypothesis in this study is the influence of SBI on foreign investment. From the results of the calculation of the partial significance test obtained the SBI tcount of 2.723 and with a significance value of 0.011 smaller than 0.05 and the value of ttable $2.042<\mathrm{t}$ count 2.723. Then $\mathrm{Ho}$ is rejected and $\mathrm{Ha}$ is accepted which means that it has a significant effect between $\mathrm{SBI}$ and PMA. Thus $\mathrm{H} 2$ which states that $\mathrm{BI}$ interest rates affect foreign investment is accepted.

\subsubsection{Influence of inflation on foreign investment}

The third hypothesis in this study is the influence of Inflation (INF) on foreign investment. From the results of the calculation of the partial significance test obtained the inflation tcount of 0.369 and with a significance value of 0.715 greater than 0.05 and the value of $\mathrm{t}$ table $2.042>\mathrm{t}$ count 0.369 . Then $\mathrm{Ho}$ is accepted and $\mathrm{Ha}$ is rejected which means that there is no effect and no significant INF on PMA. Thus H3 which states that Inflation has an effect on Foreign Investment is rejected.

\subsection{F test}

\begin{tabular}{|c|c|c|c|c|c|c|}
\hline \multicolumn{7}{|c|}{ ANOVA: } \\
\hline \multicolumn{2}{|c|}{ Model } & $\begin{array}{l}\text { Sum of } \\
\text { Squares }\end{array}$ & D1 & $\begin{array}{l}\text { Mean } \\
\text { Square }\end{array}$ & $\mathrm{F}$ & Sig \\
\hline 1 & Regression & 16,896 & 3 & 5632 & 364,546 & $000^{\circ}$ \\
\hline & Residual & 433 & 28 & 015 & & \\
\hline & Total & 17,329 & 31 & & & \\
\hline
\end{tabular}

Source: Output SPSS Vertion 24 
Based on the calculation F Test is the Fcount value is 364,546 . While the Ftable value is 2.92. Means that the Fcount value is $364,546>$ Ftable 2,92 . Then Ho is rejected and $\mathrm{Ha}$ is accepted. Based on a significance value of 0,000 smaller than 0.05 . This shows that GDP, SBI, and INF have a significant effect on FDI simultaneously. Thus $\mathrm{H} 4$ which states that Gross Domestic Product, Bl interest rates, and inflation, simultaneously affect foreign investment.

\section{Conclusions}

This study aims to analyze the impact of economic growth seen from the value of Gross Domestic Product (GDP), BI interest rates and inflation on Foreign Direct Investment (FDI) or Foreign Investment in Indonesia in 2010-2017. Based on the results of the study it can be concluded that:

1. Gross Domestic Product (GDP) has a significant impact or influence on Foreign Direct Investment in Indonesia. The highest GDP in a country shows the size of the market in the country. If the size of the market in the country is large, investors will be interested in investing in the country. Provinces in Indonesia with high GRDP such as DKI Jakarta, West Java, East Java, and East Kalimantan have an appeal to attract foreign investors so that the value of foreign investment is also high.

2. Bl interest rates have a significant impact or influence on foreign direct investment in Indonesia.

3. Inflation has no impact and is insignificant on Foreign Direct Investment in Indonesia.

4. Gross Domestic Product, BI interest rates, and inflation have a significant impact on Direct Foreign Investment in Indonesia.

\section{Suggestion}

1. Given that inflation has a negative impact on foreign direct investment, the government must be able to maintain the stability of the inflation rate. If inflation occurs because the amount of goods is disturbed, the government must immediately resolve the problem by importing.

2. Gross Domestic Product shows economic conditions, the government must be able to maintain and simultaneously increase GDP growth. Things that can be 
done by facilitating domestic business licenses so that the production of goods and services will be smoother.

3. For the government and monetary authorities (Bank Indonesia) it is expected to continue to coordinate in maintaining the stability of macroeconomic variables as an effort to increase foreign investment in Indonesia.

4. For investors must pay attention to factors that affect foreign direct investment, such as economic growth, interest rates, and inflation, so that it can be used as a basis for decision making.

5. For further researchers to add other variables such as exports, libor, minimum wages, which have the potential to affect foreign direct investment and use different analytical techniques in order to produce different perspectives on similar research.

\section{References}

[1] Dewi, Putu Kartika dan Nyoman Triaryati. 2015. Pengaruh Pertumbuhan Ekonomi, Suku Bunga dan Pajak Terhadap Investasi Asing Langsung. EJurnalManajemenUnud.

[2] Dewi, Tania Melinda dan Hendry Cahyono. 2016. Pengaruh Pertumbuhan Ekonomi, BI Rate, dan Inflasi Terhadap Investasi Asing Langsung di Indonesia. Jurnal Pendidikan Ekonomi

[3] Febriana, Asridan Masyhudi Muqorobbin. 2014. Investasi Asing Langsung di Indonesia dan Faktor-faktor yang Mempengaruhinya. Jurnal Ekonomi dan Studi Pembangunan.

[4] Jufrida, Firdaus, Mohd. Nur Syechalad, dan Muhammad Nasir. 2016. Analisis Pengaruh Investasi Asing Langsung (FDI) dan Investasi Dalam Negeri Terhadap Pertumbuhan Ekonomi Indonesia. JurnalPerspektif Ekonomi Darussalam.

[5] Pratiwi Nabilla Mardiana, Moch.Dzulkirom AR, dan Devi Farah Azizah. 2015. Pengaruh Inflasi, Suku Bunga SBI, dan Nilai Tukar Terhadap Penanaman Modal Asing dan Pertumbuhan Ekonomi di Indonesia.Jurnal Administrasi Bisnis

[6] Putra, Delta AnandaArga, Imam Mukhlis, danSugengHadiUtomo. 2017. Pengaruh Foreign Direct Investment, NilaiTukar Rupiah, dan Government Expenditure TerhadapPertumbuhanEkonomi di Indonesia. JurnalPendidikan: Teori, Penelitian, dan Pengembangan. 
[7] Rahardja, Pratama, Mandala Manurung. 2016. TeoriEkonomiMakroedisi 5. Jakarta: LembagaPenerbitFakultasEkonomiUniversitas Indonesia.

[8] Septifany, Amida Tri, R. Rustam Hidayat, dan Sri Sulasmiyati. 2015. Analisis Pengaruh Inflasi, Tingkat Suku Bunga, Nilai Tukar Rupiah dan Cadangan Devisa Terhadap Penanaman Modal Asing di Indonesia. Jurnal Administrasi Bisnis.

[9] Tambunan, Rexsy S. 2015. Pengaruh Kurs, Inflasi, Libor dan PDB Terhadap Foreign Direct Invesment (FDI) di Indonesia. JOM FEKON.

[10] Wardhani, Ditasari Puspita dan Suharyono. 2017. Pengaruh Nilai Total Ekspor dan Variabel Makro ekonomi Lainnya Terhadap Foreign Direct Investment (FDI) di Indonesia.Jurnal Administrasi Bisnis (JAB).

[11] Solow M. R. 2016. "Resources and Economic Growth". Institute Professor of Economics, Massachusetts Institute of Technology, Cambridge, MA, USA.

[12] Herzer D. 2009. "Outward FDI and economic growth”. German Institute for Economic Research (DIW), Berlin, Germany and University of Wuppertal, Wuppertal, Germany.

[13] Payne E. J. 2007. "Inflation and inflation uncertainty: evidence from the Caribbean region". Department of Economics, Illinois State University, Normal, Illinois, USA.

[14] Evert J. E. 1984. "Inflation and The Investing Borrower". University of Western Australia.

[15] Koob S. S. 1984. “Direct foreign investment: a migration push-factor?”. Queens College of The City University of New York, New York 11367, USA. 